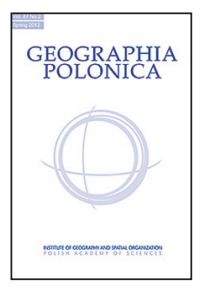 \\ INSTITUTE OF GEOGRAPHY AND SPATIAL ORGANIZATION \\ POLISH ACADEMY OF SCIENCES \\ www.igipz.pan.pl \\ www.geographiapolonica.pl
}

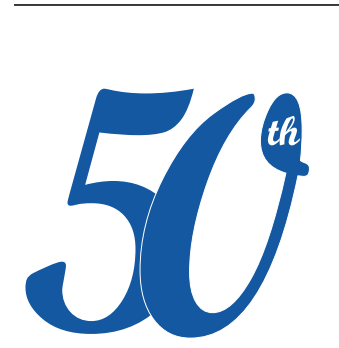

ANNIVERSARY 1964-2014

\section{GEOGRAPHIA POLONICA: A WINDOW ONTO THE WORLD. AN INTERVIEW WITH PROFESSOR LESZEK ANTONI KOSIŃSKI}

\author{
Leszek Antoni Kosiński ${ }^{1}$ • Przemysław Śleszyński ${ }^{2}$ \\ 1 Professor Emeritus \\ Sasanek 3, 05-807 Podkowa Leśna: Poland \\ e-mail: leszek.laklak@gmail.com \\ ${ }^{2}$ Institute of Geography and Spatial Organization \\ Polish Academy of Sciences \\ Twarda 51/55, 05-818 Warsaw: Poland \\ e-mails: psleszyn@twarda.pan.pl
}

To mark the 50th anniversary of Geographia Polonica, we are publishing an interview with Professor Leszek Antoni Kosiński, who was a member of its first editorial team. Professor Kosiński (b. 1929) is a distinguished Polish and Canadian geographer, participant in the Warsaw Uprising (decorated with the Home Army Cross, 1995), who was initially associated with the Institute of Geography of the Polish Academy of Sciences (1954-1967) and, after emigrating from Poland, worked mainly in Canada, at the University of Alberta (1969-1994) in Edmonton. He was associated with many prestigious scholarly organisations, including the International Geographical Union (chair of its Population Geography Commission in 1972-1980, Secretary General and Treasurer in 1984-1992) and UNESCO's International Social Science Council (member of the board

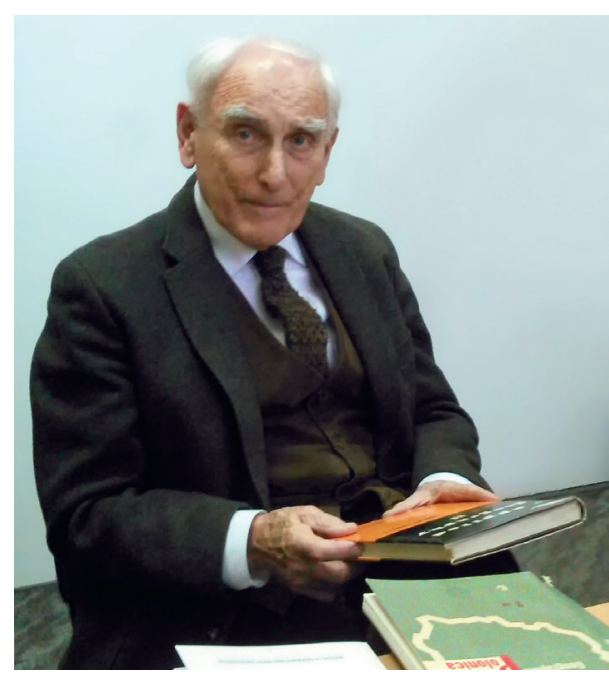

Figure 1. Professor Leszek Kosiński (the interview took place on 15 January 2014) 
in 1986-1990, and then Secretary General in 1994-2002). Author and editor of 30 books and about 100 reports, chapters and scholarly papers as well as several hundred reviews and popular science publications issued in twelve different languages in 24 countries. Honorary Member of the Geographical Societies of France (1989), Poland (1990) and Russia (1995); corresponding member of the German Akademie für Raumforschung und Landesplanung (1982), Italian Geographical Society (1989) and fellow of the Royal Canadian Society (1991); winner of the prestigious title of 'Laureat d'Honneur' awarded by the International Geographical Union (2008). Decorated with the Knight's Cross of the Order of Polonia Restituta (2008). The interview with Professor Kosiński became an opportunity to talk about the work and successes of Polish geographers on the international stage after the Second World War, and to consider the origins as well as ways of achieving those successes, which are still relevant today.

\section{- Przemystaw Śleszyński: Professor, It has been 50 years since the publication of the first volume of Geographia Polonica. This is a very long period in science and in the history of Poland.}

- LESZEK KosIŃSKI: Indeed, in order to understand those years in terms of scholarship, we cannot disregard history and the mood that prevailed in the 1950s and the 1960s in Poland. The early 1950s were a period of definite tightening of the proverbial screw, but after Stalin's death in 1953 there came the thaw culminating in the so-called October, that is a change in the leadership of the Polish United Workers' Party in late 1956 and the coming or, in fact, return to power of Władysław Gomułka'. The initial liberalisation, e.g. making it easier to obtain passports, was then gradually limited.

\footnotetext{
WŁADYSŁAW GOMUŁKA (1905-1982) - Polish politician and communist activist, First secretary of the Central Committee of the Polish United Workers' Party (19431948, 1956-1970) (this and following footnotes were prepared mostly by P. Śleszyński and B. Jaworska, with some of them being the comments of L. Kosiński - Ed.).
}

\section{- This coincided with the beginning of your professional career.}

- In 1950 I began work at the Institute of Urban Planning and Architecture ${ }^{2}$, having studied earlier at the Warsaw School of Economics, renamed Central School of Planning and Statistics when I was in my second year. I had economic geography classes with Professor Loth ${ }^{3}$, who was a very dynamic and interesting figure, like all his family, in fact. Jerzy Loth was not only a scholar, but also an Olympic activist and businessman. He had had numerous businesses all over the world before Second World War. This activity for obvious reasons was not to the communist authorities' liking and he was dismissed from the School, although shortly after the war he had even been its rector. During his lectures he would tell us stories from the life and functioning of his company, illustrating them with examples of actual transactions he had carried out; he also mentioned exotic countries in his stories. These lectures inspired me and led me towards geography. I wrote my MA dissertation under the supervision of Professor Berezowski ${ }^{4}$, whose assistant at that time was Jerzy Kostrowicki ${ }^{5}$.

\section{- But in those days it was not easy to maintain contact with the outside}

\footnotetext{
${ }^{2}$ A research institute operating from 1949-1974 and dealing with spatial planning, theory of urban planning, and architecture.

3 JERZY LOTH (1880-1967) - Polish geographer, economist and ethnographer, rector of the Warsaw School of Economics (1945-1946).

4 StanisŁaW BerezoWsKI (1910-1986) - Polish economist and social-economic geographer, from 1965 Professor at the Central School of Planning and Statistics (former Warsaw School of Economics) and the University of Łódź; specialist in transport geography and the theory of economic regions.

5 JerZY KostrowiCKI (1918-2002) - Polish economic geographer, from 1954 Professor at the Institute of $\mathrm{Ge}$ ography of the Polish Academy of Sciences, from 1973 member of the Polish Academy of Sciences; Director of the Institute of Geography and Spatial Organization, Polish Academy of Sciences (IGSO PAS) (1978-1987); Vice-President of the International Geographical Union (IGU;1980-1984), Chair of the Commission for Agricultural Typology of the IGU (1964-1976) and the Commission on Agricultural Productivity and World Food Supply (1976-1980); research into e.g. geography of agriculture - author of an internationally recognised typology (1972-1976).
} 
world. The borders were closely guarded, the 'cold war' was in full swing, people could only get passports in exceptional cases. There was no television.

- I began my studies intending to work in international trade. However, very quickly I had to give up this idea, because my life history was 'inappropriate' as far as the communist authorities were concerned. My father was a military pilot and before Second World War served as an officer of the 1st Wing in Warsaw and subsequently in the Air Force Command. After September 1939 Polish campaign he was involved in evacuation of Air Force personnel to France and later to the United Kingdom, where he served in the Polish component of the Royal Air Force. After the war he remained in the United Kingdom.

- Could you say something more about the beginnings of your professional career?

- When I was a student, I attracted the attention of Professor Drewnowski ${ }^{6}$, head of the State Commission for Economic Planning - a 'bigwig' at the time - who offered me a job. My friends said: "Are you out of your mind? It's a central government institution! With your background, it's impossible." I went to Professor Drewnowski and told him about myself. He said that, indeed, my situation was too difficult for him to take me on, but he added: "I'll give you references" and he was true to his word. Then I met Jerzy Kostrowicki (he was a demography consultant at the Institute of Urban Planning and Architecture), who said that he had been offered a full-time job and that he could not accept the offer, but perhaps I might be interested. I was.

\section{- So, first you worked in spatial plan- ning.}

- This was a period immediately after the war, when everything was basically being rebuilt from ruins, in a new socio-political

\footnotetext{
6 JAN DreWNOWSKI (1908-2000) - Polish economist, associated first with the Warsaw School of Economics (Central School of Planning and Statistics), from 1980 abroad (mainly in the United Kingdom); author of works dealing with the theory and policy of national economic planning.
}

reality, so it had to focus on several institutions and a small group of people. In 1950 the Institute of Urban Planning and Architecture moved to the Staszic Palace ${ }^{7}$, at that time still being rebuilt, which later also housed the Institute of Geography of the Polish Academy of Sciences ${ }^{8}$. My 'interview' took place in the Ujazdów Hospital, near Agrykola. It had rather personal associations, because the nurses working in that hospital shortly after the 1920 war included my mother, who came from 'Kresy', or the Borderlands?.

\section{- And how did you eventually end up among geographers?}

- From the very beginning of my work at the Institute of Urban Planning and Architecture, which I began in September 1950, I was quite frequently in touch with Kostrowicki. Sometime in mid-1953 he told me that the idea had been put forward to create an Institute of Geography at the Polish Academy of Sciences, which was being set up at the time. He suggested that I should think about it, because I might want to work there. The suggestion seemed interesting and soon I also met Professor Leszczycki ${ }^{10}$, who had been earlier Deputy Minister for Foreign Affairs.

\footnotetext{
7 The palace of the Royal Society of Friends of Learning in Warsaw, located on the Nowy Świat (Royal Route) in the city centre, erected in 1820-1823 on the initiative of Stanisław Staszic (1755-1826), a leading figure of the Polish Enlightenment and naturalist. Currently the seat of the Polish Academy of Sciences and the Warsaw Scientific Society.

${ }^{8}$ Institute of Geography of the Polish Academy of Sciences, abbreviated as IG PAS (from 1974 Institute of Geography and Spatial Organization of the Polish Academy of Sciences, from 1998 Stanisław Leszczycki Institute of Geography and Spatial Organization), a leading Polish centre of geographical and spatial planning research, founded in 1953, with headquarters in Warsaw and branches in e.g. Krakow and Toruń. Current publisher of Geographia Polonica and about 10 other periodicals.

9 During my childhood the term 'Kresy' was used to describe the eastern regions of the pre-partition Poland, which are now within the Ukrainian Republic. Many but not all Poles who had been living there have escaped after the Bolshevik Revolution of 1917 and the following troubles. This included my mother who actually had been born in Mariupol, but spent her childhood within the area known as 'Kresy'.

10 StanisŁaW Marian LeszCZYCKI (1907-1996) - Polish socio-economic geographer and political activist, main organiser of Polish geography after the
} 
- One of the founders of modern Polish geography. It is believed that the unquestionable post-war development of our discipline in Poland happened to a large extent thanks to Leszczycki and his ability to combine political activity with academic work and its organisation.

- Professor Leszczycki came from Krakow, was a member of the Polish Socialist Party before the war and knew Cyrankiewicz,11 with whom he was imprisoned in a German camp. Leszczycki's activity resembled to some extent Romer's work ${ }^{12}$. He wanted to play a role somewhat similar to that of Romer ${ }^{13}$ during the preparations of the Treaty of Versailles in 1918. After the war Leszczycki was in a very good position to achieve that; in particular, he had personal, friendly access to Prime Minister Cyrankiewicz, which opened a lot of doors. On the other hand, Professor Leszczycki had great organisational talents and was a man of action. That is why he performed many often absorbing roles at a time - he served as a deputy minister, member of Parliament, director of the Institute of Geography at the University of Warsaw,

Second World War, founder and director of the IG PAS (1953-1977); Director of the Institute of Geography at the University of Warsaw (1951-1970) and of the Institute of Geography at the Jagiellonian University (1945-1948); Member of Parliament (1945-1947); Deputy Minister for Foreign Affairs (1946-1950); extensive international activity, e.g. with the IGU (President in 1968-1972 and Vice-President in 1972-1976); in 1998 the IGSO PAS was named after him.

11 Józef CyrankieWICZ (1911-1989) - Polish socialist and communist, five-times Prime Minister of Poland (1947-1952 and 1954-1970).

12 This has recently been described in detail by EBERHARDT P., 2012. The Curzon line as the eastern boundary of Poland. The origins and the political background. Geographia Polonica, vol. 85, no. 1, pp. 35-44.

13 Eugeniusz RoMer (1871-1954) - one of the most outstanding Polish geographers with vast interests; political activist and patriot; creator of e.g. the foundations of modern Polish cartography and climatology, founder of e.g. Polski Przeglad Kartograficzny (Polish Cartographical Review) - one of the oldest publications of this type in the world; organiser of the 1934 Congress of the International Geographical Union in Warsaw, Vice-president of the IGU (1928-1938), the member of the Polish delegation sent to the peace negotiations leading to the Treaty of Versailles (1919) that set up western boundaries of pre-Second World War Poland. and created the Institute of Geography PAS and the Academy itself on the highest level.

- And what was the admission procedure you had to go through to work at the Institute of Geography?

- In 1954 I got good grades at the entrance exam for aspirantura ${ }^{14}$ at the newly founded Institute but I was not offered a place. When Professor Leszczycki heard about it, he offered me a doctoral scholarship. It proved to be better than aspirantura. I only had to submit a testimonial from my previous employer, i.e. the Institute of Urban Planning and Architecture. I saw this testimonial after a while. It was very brief: "Kosiński is a researcher at our Institute. His father was an officer before the war and now lives in England". There was no information about me, about my predispositions, skills etc. Such information was meant to discredit me. Leszczycki himself told me that, yet he did take me on and organised a doctoral scholarship for me (at the time it was possible to combine a job and a scholarship in the same institution). That is how I began working at the Institute of Geography PAS in 1954.

- Professor Leszczycki had many contacts across the world.

- Undoubtedly, he was a man of international stature, which constantly kept growing as a matter of fact. Leszczycki was always open to international contacts. Among Polish geographers he had this ability to attract and collaborate with people with similar views and panache. They were Professors Dylik ${ }^{15}$ in Łódź, Galon $^{16}$ in Toruń and Klimaszewski ${ }^{17}$ in Krakow. Leszczycki, Dylik, Galon and Klimaszewski

\footnotetext{
${ }^{14}$ Name of a doctoral programme in Poland in 1951 1958, modelled on the programme that functioned at the time in the USSR.

15 JAN DYLIK (1905-1973) - Polish physical geographer and geomorphologist, pioneer of periglacial research, founder of Biuletyn Peryglacjalny (Periglacial Bulletin), associated mainly with the University of Łódź.

16 Rajmund GalON (1906-1986) - Polish physical geographer and geomorphologist, one of the founders of the Polish school of geomorphology, associated mainly with the Nicolaus Copernicus University in Torun.

17 MieczYStaW KlimaszeWsKI (1908-1995) - Polish geographer and geomorphologist, political activist (1965-1972 member of the Council of State, member
} 
made up a leading 'quartet' and were later joined by others.

- People at the Institute of Geography PAS also included Dziewoński ${ }^{18}$, Kostrowicki...

- Both gentlemen had some international experience under their belt at the time. Kazimierz Dziewoński, who had spent the Second World War in the West, had been associated for some time with the School of Architecture and Planning, University of Liverpool, while Jerzy Kostrowicki had spent some time in the late 1940s on a scholarship at the London School of Economics and Political Science. Both knew foreign languages (English and French) and had independent contacts in the English-speaking world, which was quite rare in those days.

- It could, therefore, be said that the motivation behind the founding of Geographia Polonica was not only a desire to promote Polish accomplishments abroad, but also a need to open Poland to the world?

- It was an evolution. Already in the 1950s there were suggestions that developments in Polish geography should be published. First, there were abstracts in English and Russian of articles published in the revived Czasopismo Geograficzne (Geographical Journal) and Przeglad Geograficzny (Geographical Review), added to the Polish articles, which became more and more extensive with time. There was also a plan to issue special publications to mark international conferences, in particular a special issue of Przeglad Geograficzny (which was eventually published in 1956 to coincide with the IGU Congress in Rio de Janeiro), finally a plan to publish an institutionalised, continuous series in a Western foreign language. Undoubtedly, one of the reasons was curiosity, on both sides, in fact. We wanted to know what

of Parliament), rector of the Jagiellonian University in Krakow (1964-1972).

18 KAZIMIeRZ DZIEWOŃSKI (1910-1994) - Polish socioeconomic geographer and urban planner, associated with the IGSO PAS (until 1973 IG PAS); made very important contributions to the development of the theory of economic regions (1961, 1967), economic regionalisation (1964) as well as the economic base and functional structure of cities (1967, 1971 with M. Jerczyński). was happening in the West, and the West was interested in what was happening in Poland. At that time everyone still remembered 1934 and the Geographical Congress ${ }^{19}$, which was held with great success in Warsaw, Poland. Despite the existence of the 'iron curtain', people remembered that geography and geographers were present in Poland.

- Hence the idea of organising bilateral seminars?

- The desire to organise bilateral encounters can also be listed as one of the reasons behind the founding of Geographia Polonica. The first of these was a Polish-British seminar devoted to socio-economic geography, in September 1959 in Nieborów. After meetings with the English colleagues there were also others - with the Americans, the French, Czechs, Hungarians and others. There were a dozen or so meetings over 20 years and many friendly contacts established then were maintained for years.

- Thanks to these seminars Poland played a key role in organising geographical life in this part of Europe, when the West and East met. Many geographers from Hungary, Bulgaria and other countries of the Communist Bloc learned Polish in order to have contacts with the West through Poland. I have heard that in those days even East and West Germans would come to Poland to meet freely, because the border between them was a huge barrier.

- Indeed, in Poland it was much easier to establish contacts, and our colleagues from both the East and the West took advantage of that. Foreign literature, too, was more easily accessible here than in other countries of the Eastern Bloc. It was not only about originals, but also about overviews of literature. I myself wrote overview articles about settlement and population geography in Japan ${ }^{20}$,

\footnotetext{
${ }^{19}$ Cf. more on this topic, see article in the present issue of Geographia Polonica (JACKOWSKI A., BILSKA-WodeCKA E., SotJAN I., 2014. Geographia Polonica, vol. 87, no. 2, pp. 295-308).

20 KosińSKI L., 1958. Geografia zaludnienia i osadnictwa w Japonii. Przeglad Zagranicznej Literatury Geograficznej, no. 1, pp. 149-156.
} 
in the United Kingdom ${ }^{21}$, in Central and Eastern Europe ${ }^{22}$, the Federal Republic of Germany ${ }^{23}$, Switzerland ${ }^{24}$ and France ${ }^{25}$. I have no idea how many geographers learned Polish, but I personally know four who did. They were Gyorgy Enyedi ${ }^{26}$ from Hungary, Marin Bačvarov $^{27}$ from Bulgaria and lan Hamilton ${ }^{28}$ and Frank Carter $^{29}$ from England. I also met a Georgian geographer, Vazha V. Gujabidze, who claimed that he had encountered a modern approach to geography in Poland and that during his lectures he used a population geography textbook translated from Polish. In this context it is worth mentioning a special reporting session on 10 years of collaboration with socialist countries during which particular emphasis was placed on the work relating to geomorphology and land use ${ }^{30}$.

\section{- How did the first Polish-British semi- nar happen?}

21 KOSIŃSKI L., 1957. Uwagi o geografii osadnictwa i zaludnienia w Wielkiej Brytanii. Przegląd Geograficzny, vol. 29, no. 4, pp. 797-805.

22 KosIŃSKI L., 1967. Geografia ludności i osadnictwa w socjalistycznych krajach Europy Srodkowo-Wschodniej. Przeglad Geograficzny, vol. 39, no. 4, pp. 829-843.

23 KosIŃSKI L., 1959. Badania ludnościowo-osadnicze w Niemieckiej Republice Federalnej. Przeglad Zachodni, vol. 15, no. 6, pp. 410-417.

24 KOSIŃSKI L., 1961. O problemach geografii zaludnienia i osadnictwa w Szwajcarii. Przeglad Geograficzny, vol. 33, no. 2, pp. 287-293.

25 KOSIŃSKI L., 1961. Wybrane problemy geografii zaludnienia i osadnictwa we Francji. Przegląd Geograficzny, vol. 33, no. 4, pp. 705-715.

26 GYORGY ENYEDI (1930-2012) - Hungarian socioeconomic geographer, one of the key representatives of regional science, founder (1984) of the Centre for Regional Studies of the Hungarian Academy of Sciences, Vice-President of the IGU (1984-1992).

27 Marin BAČVAROV (1936-2006) - Bulgarian socioeconomic geographer, associated mainly with the University of Sophia and, towards the end of his life, with the University of Łódź.

28 F.E. IAN HAMILTON (1937-2002) - British socioeconomic geographer at the London School of Economics, chair of the Commission on Industrial Geography of the IGU (1976-1984).

29 FrANK CARTER (1938-2001) - British geographer specialising in human geography at the University College London (School of Slavonic and East European Studies).

30 Nauka Polska, 1965. vol. 13, no. 4, pp. 151-152.
- The initiative came from Antoni Kukliński ${ }^{31}$, who was an economist by education, but already at that time he was working as a geographer, first in Poznań and then in Warsaw. He must have been inspired by an earlier bilateral, Polish-British seminar on economics, about which people talked a lot in those days. The outcomes of the geography seminar were published separately as Problems of applied geography ${ }^{32}$. This was the first attempt to promote our accomplishments internationally on a more permanent basis, but it was not yet Geographia Polonica. As it happened, when the first Polish-British seminar was taking place, Lord Nathan ${ }^{33}$, the president of the Royal Geographical Society, came to Poland on a visit. Lord Nathan opened the conference. There is an anecdote about his visit. He came to the banquet held in Nieborów with his wife. He loved the food, especially when he was told that the chef was still from the 'Radziwitł's' times' ${ }^{34}$. He decided to go to the kitchen and congratulate the chef. Much to his disappointment, instead of a dignified man in a chef's hat, he saw a young village girl bustling about; perhaps she was a pupil of the chef, perhaps not, but she certainly was a very good cook. In any case, the Nieborów seminar must be regarded as very successful, both in scientific, organisational

\footnotetext{
31 ANTONI KUKLIŃSKI (b. 1927) - Polish geographer and economist, associated with the IG PAS, and the University of Warsaw (founder of the Centre for European Regional and Local Studies); author of publications devoted to spatial organisation and industrial geography.

32 K. DZIEWOŃSKI, L. KosińsKI (ed.), 1961. Problems of applied geography. Proceedings of the Anglo-Polish Seminar, Nieborów, September 15-18, 1959. Geographical Studies, 25, Warszawa: Państwowe Wydawnictwo Naukowe. See also: L. KoSIŃSKI, 1959. Brytyjsko-polskie seminarium geograficzne, Biuletyn Polskiego Komitetu ds. UNESCO, vol. 8, no. 25, pp. 8-10. Interestingly, in 1961 the Institute of British Geographers bought 1000 copies of that volume of Geographical Studies from the Institute of Geography.

33 Harry louis Nathan, 1st Baron Nathan (1889-1963) - British politician associated with the Labour Party; Minister for Civil Aviation (1946-1948); President of the Royal Geographical Society.

34 The palace and park of Nieborów used to belong to the powerful Radziwiłł family known for their lavish life style, especially in the 16-18th centuries.
} 
and social terms. It paved the way for subsequent encounters.

- Looking back, we can see that the collaboration of Polish geographers with the West at that time was unique, as it were, not only in comparison with other countries of the Soviet Bloc, but also when compared with other academic disciplines in Poland.

- Unlike geography, other disciplines, especially in social sciences and the humanities, for example history, were very politicised in those days. Scholars who were not party members but wanted to have serious careers did not stand much chance. The situation was different at the Institute of Geography PAS.

- Despite the numerous provisions concerning the role of Marxism in geography and such like, is it possible to say that the Institute was not politically involved, despite the fact that Professor Leszczycki was politically active and had many connections stemming from that?

- Indeed, we cannot disregard Professor Leszczycki's public activity, but it has to be said that he never pressed his colleagues to become party members. Leszczycki protected people. Among the approximately 200 employees of the Institute only a few were members of the communist party. At that time there were four of us, doctoral students: Kukliński, Wróbel ${ }^{35}$, Starke $^{36}$ and myself - and none of us was a party member. However, the circumstances and atmosphere changed over the years; in the 1960s there was even a rather serious conflict with Chilczuk $^{37}$, secretary of the party cell at the

\footnotetext{
35 AndRZEJ Wróbel (1928-1999) - Polish economic geographer, associated with the IGSO PAS, author of publications dealing with economic-geographical regionalisation.

36 Leszek StARKEL (b. 1931) - Polish geographer and geomorphologist, since 1953 associated with the Institute of Geography PAS, one of the founders of the Polish school of geomorphology, pioneer of research into natural disasters, e.g. in the Himalayas.

37 Michat ChILCZUK (b. 1926) - Polish economist and socio-economic geographer, associated in the 1960s with the Institute of Geography PAS, after termination of employment UN expert on spatial planning in Africa.
}

Institute, whose unacceptable actions were eventually curbed by Professor Leszczycki, though it required intervention at a high level.

- Speaking of Professor Leszczycki, I know a story that on one occasion he was presented with a drawing of a tightrope walker. This was to symbolise his activities - on the one hand supporting the state, and on the other making sure that the staff could develop academically without any hindrance, in particular that they could have contacts and collaborate with Western geographers.

- Fortunately, this collaboration could be continued. The next Polish-British seminar took place in Keele, England, in September 1962, followed by another one in Poland in 1966. I was the organiser and secretary of the first seminar, was away from Poland during the second and participated again in the third. These seminars, Polish-British at first, began a whole series.

- Which lasted until the 1990s. Numerous bilateral meetings of this kind and also more and more frequent 'normal' international conferences organised on various occasions even led to the publication of a special series called Conference Papers ${ }^{38}$, under which conference and seminar papers were published. In Poland the Institute was a superpower when it came to international cooperation between geographers.

- The forms of this cooperation varied, but we certainly should stress the participation of Polish scholars in the Congresses of the International Geographical Union. There were no Polish participants in the first postwar Congress in Lisbon in 1949 and in the second Congress in Washington in 1952. The next Congress was held in 1956 in Rio de Janeiro and the authorities agreed to send a five-man delegation (J. Barbag, J. Dylik, M. Klimaszewski, J. Kostrowicki, S. Leszczycki). An important breakthrough came probably with the 1960 Congress in Stockholm,

\footnotetext{
38 Conference Papers - irregular series published by the IGSO PAS, in 1988-1996, totalling 25 volumes.
} 
for which a special English-language issue of Przeglad Geograficzny was prepared. At that Congress Poland aroused great interest among the Americans, who in 1964 gladly came to a bilateral seminar, which I organised ${ }^{39}$. It is a broader issue - I wrote an article about Polish-IGU contacts published in Historia geografii polskiej ${ }^{40}$ (History of Polish geography)..

- We could probably say not only that the sources of Geographia Polonica lay in bilateral meetings, but that from the very beginning these were meetings with outstanding geographers, for, after all, British or American geography was on a high level at the time, it was absolutely in the top flight internationally (as it is today). However, it was also a time of expansion of Soviet geography and its influence on the countries of Eastern Europe, which had had different academic traditions before the war, countries like Poland or Hungary. This was not conducive to contacts with the West.

- It wasn't. On both sides there was a sense of isolation, although Poles, in fact, were the most emphatic in their openness to the world. However, the only open door was open towards the Soviets and the opening was not very wide at that. 1950 was marked by the founding of Przeglad Radzieckiej Literatury Geograficznej (Soviet Geographical Literature Review), later transformed into Przeglad Zagranicznej Literatury Geograficznej (Foreign Geographical Literature Review). In the case of the former, it was an attempt to 'play two pianos at once' to avoid accusations of having too Western leanings. But there were also actions that had very much more substance to them. For example, I wrote an article on Russian population geography,

\footnotetext{
39 KOSIŃSKI L., 1964. Amerykańsko-Polskie seminarium geograficzne. Biuletyn Polskiego Komitetu ds. UNESCO, vol. 9, no. 74, p. 21.

40 KosIŃSKI L., 2008. Międzynarodowa Unia Geograficzna [in:] A. Jackowski, S. Liszewski, A. Richling (eds.), Historia geografii polskiej. Warszawa: Wydawnictwo Naukowe PWN, pp. 477-488.
}

going as far back as the 19th century, ${ }^{41}$ and it was well received by the Soviet side. The population geographer Vadim Pokshishevsky ${ }^{42}$, who had Polish roots, in fact, wrote a friendly review of that volume, correctly summarising my article.

- A breakthrough came in 1953. Significantly, the date of the founding of the Institute of Geography PAS fell six months after Stalin's death, in October 1953.

- I think that Stalin's death may have 'released the brakes'. It was as if we had seen the first small star, which in 1956 came to shine very brightly indeed. In any case, the Polish Academy of Sciences established after the Second World War was modelled on its Soviet equivalent. At that time, the Polish Academy of Arts and Sciences ${ }^{43}$, which tried to continue pre-war traditions and maintain some continuity in Polish scholarship, was displeased by the emergence of the Polish Academy of Sciences.

- Do you remember, Professor, how Geographia Polonica came into being?

- Discussions about a desire to create such a series, or a Polish journal in a foreign language, were held during various meetings in the early 1960s. I mean here in particular meetings of the Committee on Geographical Sciences of the Polish Academy of Sciences or the National Committee of the International Geographical Union, both chaired by Professor Leszczycki. The discussions were also held during meetings of the Scientific Council of the Institute of Geography PAS, during which Leszczycki also played a leading role. During a meeting on 9 April 1962 the Council set up a special Commission composed of Professors Jerzy Kostrowicki, Stanisław

\footnotetext{
${ }^{41}$ KosIŃSKI L., 1958. Radziecka geografia zaludnienia i osadnictwa. Przegląd Zagranicznej Literatury Geograficznej, 1, pp. 1-76.

42 Vadim V. PokshisheVsky (1905-1984) - Soviet economic geographer, associated with the University of Moscow.

43 Polska Akademia Umiejętności - one of the oldest and most prestigious scholarly societies in Poland, established in 1872 following a transformation of the Krakow Scholarly Society.
} 
Leszczycki and Jerzy Kondracki44, the task of whom was to submit a formal, documented application to the authorities of the Polish Academy of Sciences for permission to set up a new geographical publication aimed at the international market. With all the formalities completed, the Scientific Council of the Institute of Geography PAS, during its meeting on 31 May 1963, established the Geographia Polonica Editorial Board composed of Editorin-Chief - Professor Stanisław Leszczycki, members - Professor Jerzy Kondracki, Professor Jerzy Kostrowicki, Secretary to the Board - Docent ${ }^{45}$ Leszek Kosiński.

\section{- How was this organised?}

- It fell to me to collect and prepare the articles. Paradoxically, in the early days all this was incidental to my other work, as it were. There was no professional publishing editor, editorial staff, secretary etc. Initially, we would publish the results of seminars and information about Polish geography. The first volumes were general in nature, overview-like, later they were given specific profiles.

\section{- But why was it you that did all this work and became the secretary to the editorial board?}

- Why did I become the secretary? Good question. I don't quite know. Perhaps my experience was appreciated. As it happened, I had earlier been secretary to the editorial board and organised the work associated with the publication of a major volume of Prace Geograficzne or Geographical Studies devoted to the regeneration of small towns ${ }^{46}$. In addition, I knew English, German, and a bit of French and Russian. These two reasons, editorial and linguistic experience, may have

\footnotetext{
44 JeRZY KONDRACKI (1908-1998) - distinguished Polish physical geographer, associated mainly with the University of Warsaw, author of well-known publications on physical-geographical regionalisation.

45 Academic title below full professor at some European universities.

46 Dziewoński K., KieŁczewska-Zaleska M., KoSIŃSKI L., KOSTROWICKI J., LESZCZYCKI S. (eds.), 1957. Studia geograficzne nad aktywizacja małych miast., Prace Geograficzne, 9, Warszawa: Instytut Geografii PAN.
}

been why I was entrusted with the job of secretary at Geographia Polonica.

- Knowledge of English, or any other Western language in fact, was not common at the time. A lack of this skill was a serious hindrance, especially for young geographers, not only with regard to personal contacts, but also the possibility of reading the literature.

- I was lucky, because at the Warsaw School of Economics from the very beginning we had to learn two foreign languages, one on an advanced level, and the other starting from the beginner's level. The only language I had a moderate knowledge of was German, so I did not have much choice. I chose German as my advanced language and English as my second language. We were taught English by an excellent young teacher and towards the end of the first year we were able to communicate in that language. In addition, in 1950 a representative of the Church of Brethren came to the School and offered to organise a free language camp for Polish students in the form of a month-long stay in Ostróda in Masuria. This was extraordinary, because at that time no one offered anything for free to anyone. During our stay there our task was to work on building a playground for children and to respect specific rules. This meant being forced to learn English, with all the instructions and announcements being given in English. My participation in this enterprise improved my English a lot. The organisers encouraged us to visit the library of the American Embassy in Warsaw after our return and to read anything we could lay our hands on.

\section{- Wasn't this suspect at the time?}

- Of course it was, though at the beginning we did not realise that. A friend of mine had this adventure. He had just left the embassy and got into a trolleybus. He saw a man desperately trying to catch the bus, so he helped him to get on. It turned out that the man was from the secret police and had been following my friend, because, of course, he wanted to 'question' him about his visit to the American embassy. My friend was sorry he had helped the man get onto the bus and this 
is how our visits to the embassy ended. Coming back to Geographia Polonica, it was probably my experience with 'small towns' and knowledge of English that were decisive in my becoming the secretary.

- From what I understand, Geographia Polonica and post-war Polish geography in general were successful because there were already, at the very beginning, people who knew very well that science could not be locked within national borders and that it was universal and had to be based on cooperation.

- Indeed, and an important role was played by a methodological conference in Osieczna in February 1955, during which various aspects of geography were extensively discussed and a new way of systematizing the discipline has been proposed. The conference participants were open-minded people, who understood the value of international contacts.

- But in Poland not everyone shared the view that openness to the world was a must?

- It seems that some institutions were quite provincial in this respect. Also, cooperation did not always run smoothly, there were differences of opinion or even personal misunderstandings. For instance, the relations between Professor Leszczycki and Professor $\mathrm{Jahn}^{47}$, who was also very active on the international stage, were not very good.

- Wasn't there an element of internal competition?

- I would call it regionalism. For example, Professor Olszewicz ${ }^{48}$ was based in Wrocław, Professor Galon - in Toruń, and Professor Klimaszewski in Krakow. There was also another situation: Olszewicz who directed a section of the Institute of Geography PAS reached the retirement age and somebody - I don't remember who, but in any case someone

\footnotetext{
47 Alfred JAHN (1915-1999) - Polish geographer, geomorphologist and polar zone researcher, in 19621968 rector of the University of Wrocław; 1971-1975 President of the Polish Geographical Society.

48 BolestaW OlszeWICZ (1893-1972) - Polish geographer and historian of cartography, in 1933-1939 curator of the University of Warsaw Library.
}

not very friendly - asked Professor Leszczycki whether the section run by Olszewicz would be closed. Leszczycki replied that there was no need for that, because Olszewicz was doing a god job, should continue doing it, and so we should forget his age. In such situations Professor Leszczycki was not a stickler for rules and trusted his staff.

- Working for Geographia Polonica was not your only job?

- I was primarily a population geographer by profession. Geographia Polonica was quite incidental to my main work. With time the editorial board acquired a new secretary, Mrs Teresa Lijewska, with whom I got on very well.

- What about acquiring articles? Did anyone make decisions about that, choose topics, prepare any publishing plans?

- There weren't really big discussions and decisions or even meetings of the editorial team. If anything, there were only my working meetings with Professor Leszczycki. When it came to thematic issues, we would invite specific authors to submit articles, people who were strong in a particular field, specialising in specific areas.

- Were there any publishing problems at the beginning? We often hear stories about shortage of everything, including paper, in those days. And there was censorship as well.

- The technical-publishing side was dealt with by our publishing unit. As far as I know, there were usually no such problems. Of course, there was censorship, but I don't remember any problems with it. There was a captain from the General Staff, who was delegated to come to us as a censor; he was even a geographer by education. I remember a situation associated with that study of small towns. I went to the censor, who resided in Rakowiecka Street, bringing with me the town maps we wanted to publish. They were quite detailed maps at a scale of 1:15,000. The censor saw them and said it was absolutely impossible. He did like the idea, but he would not give his consent, because he was afraid that he would be given an earful from 
his superiors. I tried to explain to him that these were small towns, like Ciechanowiec or Drohiczyn, in which nothing was ever happening from the point of view of national security, that it was about rehabilitation and development of these towns. Eventually the decision was that if we were not allowed to print the maps in their entirety, we would have to print them in fragments. In this way we published all the town plans, almost in their entirety, with just some peripheral fragments being cut, and with appropriately modified titles, of course. All in all, I don't remember having any particular problems with the publishing of Geographia Polonica. We would simply routinely send articles to Mysia Street ${ }^{49}$ and we would basically forget about it. Nevertheless, we tried to be careful not to put ourselves at risk. In any case, our series was not about journalistic writing and the topics discussed were fairly neutral.

- Was there any programme, were any plans made for the immediate future?

- Our work was primarily determined by the congresses of the International Geographical Union, which were held every four years. Something always had to be prepared for the congress and we made sure the publications would reach the right people. The way it was technically organised was that each Congress participant, that is each national delegation, had their own pigeonhole in a huge mail sorting cabinet. The things we wanted to distribute during the Congress were put into the relevant holes. In those days copies of the journal were not given to all participants, because that would have been impossible for obvious reasons, expensive as the printing was. Usually, we gave copies to the heads of the various delegations.

- Today we would call it precision marketing. But I do realise that the times were different then and there were, in fact, no other media apart from print. The introduction to the first volume of Geographia Polonica, by Professor Leszczycki, tells

\footnotetext{
49 Between 1946 and 1990, a building on this Warsaw street housed the Central Office for the Control of the Press, Publications and Shows, i.e. censor's office.
}

us that every year, Polish geography produced about six-eight thousand pages of printed matter. Today we publish much more; the Bibliography of Polish Geography lists three-five thousand items every year, each item has several to a dozen or so pages (many more in the case of monographs), and there are also many places not included in this bibliography, where Polish geographers publish their articles or books, for instance abroad. Fifty years ago the literature was much less extensive, but it did matter more.

- It did, and an opportunity for making publications better known was provided by exchanges between institutions or people. Again we need to refer to Professor Leszczycki, who had two 'hobby horses' in his work. The first was the library, through which he made sure journals would be exchanged, and the second was atlases.

- The library of the present-day Institute of Geography and Spatial Organization PAS is still regarded as one of the largest institutions of this kind in the world.

- That is thanks to Professor Leszczycki. Though not only thanks to him. A very interesting chapter in the history of the Institute is associated with Professor Bogodar Winid ${ }^{50}$. He was very eccentric, perhaps even mad - in the best sense of the word, of course. In the early post-war years many people would organise trips to former German territories now incorporated into Poland (known as 'Recovered Territories') to look for objects useful in organising life in devastated and impoverished country. The Institute had access to a lorry which could be used for such expeditions. Winid would go, too, and, much to the driver's regret, he would bring back tons of books from abandoned libraries, mainly German publications. Sometimes he would also bring office or library furniture. In those days nobody was interested in books

\footnotetext{
50 BogodAR WINID (1922-1996) - Polish geographer and cartographer, one of the founders of the Institute of Geography, University of Warsaw after the Second World War.
} 
and nobody wanted them - others went there to bring furniture, china, cars. Winid went there to bring books, he 'pilfered' them, again, in the positive sense, thus saving them from destruction. Then in our 'dungeons' in the Czetwertyński/Uruski Palace in Krakowskie Przedmieście, where the University of Warsaw and the Polish Academy of Sciences had some rooms, we would partly organise and catalogue these collections.

- Was Geographia Polonica meant to present the achievements of the staff of the Institute of Geography PAS or of all Polish geographers? This would have been understandable, because the Institute's position at the time was very strong. The Institute was a leader, if not a monopolist even, in many aspects, especially regarding international contacts.

- There was a rather clear division. After the Second World War universities were more like educational establishments and their main, though not the only, task was teaching. The Academy, on the other hand, was given the green light when it came to research. However, the assumption was that Geographia Polonica would promote the work of all Polish geographers regardless of their position.

- What then was the first reaction to such a publication?

- At the Institute of Geography PAS it was enthusiastically received, as a breath of fresh air. This also showed that more people from the Institute travelled abroad. For instance, more geographers from the Polish Academy of Sciences than from the universities attended the IGU congresses. It even seems to me that some provincial universities did not appreciate the importance of international congresses and publications. I, for example, saw the University of Lublin as more circumspect, conservative. Of course, there were exceptions among the universities - there were more open and dynamic professors like Galon in Toruń, Klimaszewski in Krakow, then Jahn in Wrocław or Dylik in Łódź, who held prominent positions in physical geography.

\section{- Did Poles publish their papers abroad?}

- No, not really. Getting into Western periodicals was almost impossible for Poles at the time. Socio-economic geographers who had their articles published by foreign periodicals included Leszczycki, Dziewoński and Kostrowicki. Now I understand your question about obtaining articles.

- Today, when an author from Poland wants to publish an article in English, he or she not only can choose among a dozen or so domestic titles, both dealing with geography in general and focusing on specialist topics, but, above all, has access to many foreign publications. In the 1950s and 1960s it was Geographia Polonica that remained the main, if not the only, overseas distribution channel.

- As I have already said, international congresses and conferences were always a pretext for publishing special issues and such occasional publications were prepared by various centres outside the main publishing series. Information travelled the other way round as well. Participants would bring back foreign publications, distributed during congresses, with them. Reports on these events were published as well. Particularly detailed was the report on the 25th Congress in Paris, in $1984^{51}$.

- For obvious reasons, stemming from concentration of research at the Institute of Geography PAS, contributions of authors must have been uneven. An interesting picture emerges, as we analyse citations of Polish periodicals from that period. Today, we can see that there are two major Polish geographical periodicals: Geographia Polonica and Przeglad Geograficzny. They have made the biggest contribution to the development of research, especially in its conceptual-theoretical

${ }^{51}$ Kostrowicki J., RozłUCKI W. (eds.), 1985. XXV Międzynarodowy Kongres Geograficzny: Paryż - Alpy 1984. Przegląd Zagranicznej Literatury Geograficznej, 3-4. 
aspect, both domestically (Przegląd Geograficzny) and in the sense of promoting various ideas internationally (Geographia Polonica).

- There was also a well-konown periodical dedicated to geomorphology, Biuletyn Peryglacjalny, edited by Professor Dylik in Łódź.

- It is a pity it has been discontinued the last issue came out in 1999 - it was published for 46 years. The Polish contribution to periglacial research is appreciated in the West today. There are several other Polish specialities of this kind from the post-war period, specialities that brought new elements to international scholarship. In socio-economic geography these undoubtedly include achievements relating to the theory of economic regions and settlement systems (K. Dziewoński), typology of agriculture (J. Kostrowicki), urban planning (B. Malisz ${ }^{52}$ ). Often quoted papers from that period include those of $\mathrm{S}$. Leszczycki, mentioned in our conversation so many times, as well as A. Kukliński, P. Korcelli ${ }^{53}$, Z. Chojnicki ${ }^{54}$, R. Domański $^{55}$, M. Kiełczewska-Zaleska ${ }^{56}$, T. Czyż ${ }^{57}$,

52 BOleSŁAW MALISZ (1910-1995) - Polish urban planner and architect, associated with, among others, the IGSO PAS, co-founder of the Polish school of spatial planning, author of the threshold analysis method (1971).

53 Piotr Korcelli (b. 1939) - Polish socio-economic geographer, director of the IGSO PAS in 1987-2010; Editor-in-chief of Geographia Polonica in 1988-2002; author of studies devoted to e.g. development of metropolitan areas, migrations of populations and other population studies.

54 ZBYSZKO CHOJNICKI (b. 1928) - Polish socio-economic geographer, pioneer of Polish quantitative geography, associated with the Adam Mickiewicz University in Poznań

55 RYSZARD DOMAŃSKI (b. 1928) - Polish geographer and economist, author of the concept of non-linear system dynamics, rector of the Poznan School of Economics (1969-79).

56 Maria KiełCZEWSKA-Zaleska (1906-1980) - Polish socio-economic geographer, author of numerous studies relating to settlement geography in Poland.

57 Teresa CZYŻ (b. 1938) - Polish socio-economic geographer, one of the representatives of Polish quantitative geography and the Poznan school of geography, associated with the Adam Mickiewicz University in Poznań.
M. Jerczyński ${ }^{58}$, T. Lijewski ${ }^{59}$, S. Misztal $^{60}$, J. Grzeszczak ${ }^{61}$, G. Węcławowicz ${ }^{62}$, P. Eberhardt ${ }^{63}$ and yourself - nearly all of them worked at the Institute of Geography PAS at the time. When it comes to such comparisons, there are compilations from the 1970s made by Harris ${ }^{64}$, according to which Geographia Polonica had very many citations in those days; depending on the criteria used, it was even ranked first or fourth in the world.

- Harris was very friendly to Poland. He was an extraordinary man, open to cooperation. He really wanted everything to be done the way it should be done. For two terms, between 1968 and 1976, he was Secretary General of the IGU.

- So during his first term he was there with Professor Leszczycki, who in 19681972 was President of the IGU, as the only Pole in history.

- Yes, and their collaboration was extremely successful. Incidentally, Harris probably

\footnotetext{
58 MAREK JeRCZYŃSKI (b. 1941) - Polish socio-economic geographer associated with the IGSO PAS, author of studies dealing with urban functional typology and settlement studies.

59 TeOfIL LIJEWSKI (1930-2010) - Polish economic geographer, associated with the IGSO PAS, author of publications dealing with transport development, commuting, tourism and spatial organisation.

60 StanisłaW Misztal (b. 1929) - Polish economic geographer associated with the IGSO PAS, known for his industrial geography and spatial organisation studies.

61 JerZy GRZESZCZAK(b. 1932) - Polish socio-economic geographer associated with the IGSO PAS, known especially for his studies into economic geography, including industrial and urbanisation issues.

62 Grzegorz WęCŁaWOWicz (b. 1943) - Polish socio-economic and urban geographer associated with the IGSO PAS, known especially for his studies into social geography, e.g. of Warsaw.

63 Piotr Eberhardt(b. 1935) - Polish socio-economic geographer associated with IGSO PAS, known for his studies of population and ethnic geography, spatial organisation and geopolitical issues, co-author of a wellknown study of the delimitation of urban-industrial agglomerations in Poland (1971).

64 Chauncy D. Harris (1914-2003) - American geographer, pioneer of modern urban research; President of the Association of American Geographers (1957); Secretary General and Treasurer of the IGU (19681976), author of multiple nuclei model (1945, with Edward Ullman).
} 
played an important role in supporting Leszczycki's candidacy and eventual election to the office. It is worth looking behind the scenes of these elections held during the congresses. There were often power games and intrigues among the candidates supported or opposed by various national delegations.

- Probably linked to the rivalry between the West and the Communist Bloc?

- For example, Innokenti Gerasimov ${ }^{65}$, director of the Institute of Geography of the Soviet Academy of Sciences, believed he had the right to represent the world of socialist states. Before each congress he would convene a meeting in Moscow, a meeting during which a joint course of action was decided, for instance, whom to vote for or whom to admit to the Union. Professor Leszczycki was very critical of such attempts at unity; he was always independent and, in particular, he did not accept Gerasimov's dictatorial inclinations. In 1964 Gerasimov was a candidate for the Presidency of the IGU, but shortly before the vote a telegram came from Moscow saying that he could not stand; no reason was given. It was too late for him to appeal from this decision and he had to withdraw. He was very displeased and worried, but others were happy, even showing this quite clearly - like the Poles for example - or more 'diplomatically', like the Czechs. In the end, at the last moment Professor Shiba Chatterjee ${ }^{66}$ from India was put forward as a candidate; he was elected for the 1964-1968 term. This accidental election was not very good for the Union, as a President he was attempting to undermine the position of Professor Hans Boesch ${ }^{67}$, a very competent Secretary General and Treasurer.

65 INNOKENTI P. GERASIMOV (1905-1985) - Soviet physical geographer and pedologist, director of the Institute of Geography of the Soviet Academy of Sciences.

66 ShiBa P. Chatterjee (1903-1989) - Indian geographer associated with the University of Calcutta; President of the IGU (1964-1968).

67 Hans H. BOESCH (1911-1978) - Swiss economic geographer, originally a geologist, associated with the University of Zurich; Secretary General and Treasurers of IGU (1956-1968).
- What was the situation like in 1968 ?

- Leszczycki, too, had an ambition to be elected to this office and he eventually was. Even before that he had become known internationally both as a scholar and organiser of geography in Poland, and as a geographer making his contribution to world geography. He was active in the IGU commissions, and in 1964-1968 he was the Union's Vice-President. It is worth adding that in 1983 he received the IGU's 'Laureat d'Honneur' award.

- You were the second Pole who had a career in the IGU management. You were elected Secretary General for two terms, in 1984-1992.

- During the 25th IGU Congress in Paris, for the first time ever, two candidates were put forward for this office. This was a decision of the chair, Akin Mabogunje from Nigeria $^{68}$. The Americans proposed Fuchs ${ }^{69}$, with the support of the committee and, above all, the outgoing Board of the IGU. Fuchs was also supported by the national committees of Australia, Germany (FRG), India and Japan, I was put forward by Canada with the support of Austria, Bangladesh, France, Mexico, Poland, Sweden and Uganda. There was always some friction between the USA and Canada, connected with their rivalry, depending on the situation. A decision was made that both candidatures would be put to a vote, and the result surprised the Americans, because I got 33 votes, while Fuchs - 22. Later, during unofficial meetings, I learned that my candidature was opposed by the Soviet delegation as well as the former President of the IGU Michael Wise ${ }^{70}$. He told me in a conversation (it was a bit about playing on stereotypes):

\footnotetext{
68 AkinlawON Lapido Mabogunje (b. 1931) - Nigerian socio-economic geographer, associated with e.g. the University of Ibadan; President of the IGU in 19801984 (and its three-time Vice-President); interests include the problems of urbanisation and socio-economic development; holder various offices in economic institutions, e.g. President of the Federal Mortgage Bank of Nigeria (2002-2007).

69 Roland J. Fuchs (b. 1933) - American socio-economic geographer. President of the IGU from 19882002.

70 MiChael J. Wise (b. 1918) - British socio-economic geographer, held a number of offices, e.g. President
} 
"You shouldn't be so anti-Russian. Because you, Poles,... If you get invited, you should go." I replied that I had no intention of discriminating against anybody or refusing anybody, and that I intended to hold my office as best as I could. If any member state invited me and covered the expenses, I would certainly not refuse the invitation. Later it turned out that over my eight-year term I went on three such delicate, 'diplomatic' visits - to the USSR, Israel and South Africa. Very successful they must have been, if I was made an honorary member of the Russian Geographical Society and was given the Medal of the South African Geographical Society.

- There is no doubt that in order for Polish geography to succeed internationally, and for Geographia Polonica to make its mark, we needed a friendly attitude on the part of geographers from other countries.

- I can list many friends of Poland at the time. They were first of all the Brits and the Americans, who took part in our bilateral seminars. From the United Kingdom - Toni French $^{71}$, Frank Carter ${ }^{72}$, Richard Osborne ${ }^{73}$, Keith Edwards ${ }^{74}$, Geoffrey North ${ }^{75}$, Edwin Brooks ${ }^{76}$. From the USA: Chauncy Harris,

of the IGU (1976-1980); associated with e.g. the London School of Economics.

71 TONI FrenCH (1929-2012) - British socio-economic geographer associated with University College London and the School of Slavonic and East European Studies, honorary secretary of the Royal Geographical Society (1986-1994).

72 Francis 'Frank' Carter (1938-2001) - British geographer specialising in human and historical geography especially of Central and Eastern Europe at the University College London (School of Slavonic and East European Studies).

73 Richard H. Osborne (b. 1925) - British socioeconomic geographer associated with the University of Edinburgh and the University of Nottingham.

74 Kenneth Charles EdWARds (1904-1982) - British landscape geographer associated with the University of Nottingham.

75 GeOfFrey NorTH (b. 1929) - British geographer associated with the University of Manchester.

76 EDWIN BROOKS (b. 1929) - British-Australian socio-economic geographer and politician, Dean of e.g. the Charles Sturt University in New South Wales, 1982-1988.
Norman Pounds ${ }^{77}$, Allan Rodgers ${ }^{78}$ and Wilbur Zelinsky ${ }^{79}$.

- Some of them knew our country well. Frank Carter wrote a detailed monograph on Krakow.

- All in all, it was an interesting period, when the English would send their young, promising people to all the Soviet Bloc countries. Ian Hamilton, a protégé of Wise, came to Poland and soon married a Pole. Frank Carter went to Czechoslovakia and he, too, married a Pole who interviewed him. Paul Compton ${ }^{80}$ went to Hungary; he married as well, though not a Pole but a Hungarian, and lived for some time in Hungary. We could say that women played an important role in establishing and maintaining international relations. Another friend of Poland was Harold Brookfield ${ }^{81}$ from Australia. In Mexico we had María Teresa Gutiérrez de MacGregor ${ }^{82}$ - a great friend of Professor Leszczycki; she visited Poland several times. They all supported Polish geography in a variety of ways, with contacts being established through official and private channels. These contacts spread incredibly and led to new ones.

- And what about support for Geographia Polonica in Poland?

- In Poland a very positive role was played by Professors Dziewoński - a faithful associate of Leszczycki's - Jerzy Kostrowicki,

\footnotetext{
77 Norman J.G. Pounds (1912-2006) - English geographer active in the USA, representative of regional geography, Professor of Geography and History at Indiana University, Bloomington (USA).

78 Allan Rodgers (1922-2011) - British economic geographer associated with the Pennsylvania State University.

79 Wilbur ZeLINSKY (1921-2013) - American social geographer, in 1972-1973 first director of the Population Issues Research Center, author of the mobility transition theory (1971) and pioneer of cultural geography.

80 PAul COMPTON (b. 1938) - British geographer and demographer specialising in Eastern Europe.

81 Harold C. Brookfield (b. 1926) - British-Australian geographer specialising in rural research; Chair of Geography at the University of Melbourne (19761982).

82 María Teresa Gutiérrez de MacGregor (b. 1927) - Mexican geographer, associated with the Universidad Nacional Autonoma de Mexico, Vice-President of the IGU in 1984-1992; research into urban and population geography.
} 
Rajmund Galon, and Mieczysław Klimaszewski, who had an outstanding student in the person of Leszek Starkel. When it comes to Klimaszewski, he was greatly supported by Leszczycki; they both came from Krakow. Thanks to this support, Klimaszewski became a Member of Parliament and then even a Member of the Council of State. Although he was not a member of the Communist Party, this was much better for us. The saying was that someone who was friendly and did not belong to the party was more valuable than a party member.

\section{- You were a member of the editorial board from the beginning of the journal, but not for long?}

- Until about 1967, when I left Poland intending to return, but, as it turned out, for a long time, for ever, in fact. When Gomułka ${ }^{83}$ issued his statement in $1968^{84}$, which we received from the consulate, that academic staff who had caused the trouble would be promoted and assessed on the basis of their social background, political activity and professional activity (in my case only my professional activity could be subject to any assessment), I decided to wait for the end of those dark days abroad. Unfortunately, my passport was taken away and quite unexpectedly I was pushed into permanent emigration. First, I worked at several universities in the USA and in 1968 I settled with my wife in Canada. I started working there at Queen's University in Kingston (Ontario), and worked the longest (from 1969 till 1994) at the University of Alberta in Edmonton. In 1994 I reached the age of 65 and retired. Then I applied for the position of the Secretary General of UNESCO's International Social Science Council in Paris and I won the competition and moved to France. I held that position for eight years, until 2002, and then I retired for the second time.

\footnotetext{
${ }^{83}$ First Secretary of the Central Committee of the Polish United Workers' Party at the time, op. cit.

${ }^{84}$ March events - a political crisis linked to student protests in March 1968, mainly at the University of Warsaw and in Gdańsk, provoked by the removal from the University of dissident students of Jewish origin.
}

\section{- Thanks to Geographia Polonica and not only thanks to that journal you did remain in touch with Polish geogra- phers?}

- In Poland I was always close to Leszczycki, my contacts with him were the best and lasted until he died. I was in touch with other people as well, first of all with Andrzej Gawryszewski ${ }^{85}$ and with Julitta Grocholska ${ }^{86}$. When it comes to Julitta, ours was a double friendship, as it were. First of all, she was my assistant at the Institute of Geography PAS. Secondly, she married my war-time friend Michat Grocholski ${ }^{87}$, like me, member of the clandestine Szare Szeregi (Grey Ranks) ${ }^{88}$ and participant in the Warsaw Uprising ${ }^{89}$. During the war I lived close to the Grocholskis, they had ten children and I was friends with one of the brothers, Remigian ${ }^{90}$. He was a member of the "Zośka" battalion ${ }^{91}$ and it so happened that shortly after the outbreak of the Uprising, on the very first day, he got injured. Thanks to this he could be classified as wounded before the Uprising and this may have saved his life, when the Germans were finishing off wounded insurgents. He later found himself in Italy and France, and many years later

\footnotetext{
${ }^{85}$ ANDRZEJ GAWRYSZEWSKI (b. 1939) - Polish socio-economic geographer and cartographer, associated with the IGSO PAS, known for his work on e.g. population geography.

86 JulitTA GROChOLSKA (b. 1935) - Polish socioeconomic geographer, associated with the IGSO PAS, member of the Society of Polish Urban Planners, known for her work on e.g. land use and spatial planning.

87 Michat GROCHOLSKI (b. 1929) - Orientalist, in 1992-1997 Consul-General of the Republic of Poland in Chicago.

${ }^{88}$ An underground scouting organisation which continued the tradition of the pre-war Polish Scouting Association during Second World War.

${ }^{89}$ An interview with Professor Kosiński concerning his participation in the Warsaw Uprising (Powstanie Warszawskie) was recorded in 2005 in the Oral History Archives (http://ahm.1944.pl/Leszek_Kosinski, in Polish).

90 Remigian GROCHOLSKI (b. 1928) - mechanical engineer, lives in France.

91 Polish scouts' battalion created during Second World War and heavily involved in fighting in the Warsaw Uprising (1944) against the German occupation, part of the Grey Ranks (Szare Szeregi) and operating as part of the Home Army (the biggest underground army in occupied Europe during the Second World War).
} 
we met in Paris, in the Polish Embassy, on the feast of 11 November. I am still in touch and on friendly terms with the Grocholski family. When it comes to professional contacts, I am a proud honorary member of the Polish Geographical Society.

- Was there any noticeable evolution in the content of Geographia Polonica, a clash of views e.g. between traditional or humanistic geography and quantitative geography, a dispute that is still very vivid today in Poland?

- When I was the secretary to the editorial board, I don't think there were such disputes. Qualitative geography came a little bit later. On the other hand, there was a dispute between regional geography and so-called applied geography; people tried to explain to what extent geography should serve society. We had contacts with the French in this field. The first francophone at the Institute was Marcin Rościszewski92. His main field was political geography, but there was no 'climate' for it at the time, so bigger successes came later. Before him, there was Barbag $^{93}$. There was a very serious dispute at the time over political geography, whether it should exist, and if so, to what extent and in which direction. Of course, disputes also concerned geopolitics.

- Were there any particular articles you did not manage to publish?

- No, not really. I would receive articles in Polish and we would translate them through Polish translators. The translations would then be sent to an English or American friend of ours for final proofreading. The texts were 'honed' by people like Hamilton, Brooks and Carter, and there was always double linguistic verification. It's a pity we did not publish their names, because this was a considerable effort on their part.

\footnotetext{
92 MARCIN RościszeWSKI (1929-2002) - Polish socio-economic geographer associated with the IGSO PAS, known for his work on political geography.

93 JÓZEF BARBAG (1903-1982) - Polish political geographer, author of the only textbook on political geography in the People's Republic of Poland (1971), Professor at the University of Warsaw.
}

- Were there articles that were published but it turned out later that they were not appropriate and this caused some problems?

- I don't remember such situations either, because we tried to get the best quality material. There was no problem with that. Usually, the authors and editors responded in the affirmative, because they wanted to be 'available' abroad. This applied to e.g. the IGU congresses, for which we prepared special issues. It happened in the case of the 1960 congress in Stockholm, and even before, that there was a special Englishlanguage issue of Przeglad Geograficzny in 1956. Once we published an atlas and a brochure to mark the occasion.

- Marketing and technical issues were completely different in comparison with what they are today, though the objective was the same.

- At some point the question of the cover came up. We held an informal competition. In the end, it was probably designed by cartographers from the Institute of Geography PAS, though it is difficult to remember specific names after fifty years. Today the cover is completely different.

- Like the entire layout. The journal conforms to international standards; this requires a lot of exhausting background work, which is increasingly time-consuming, but without which no one can compete on the international publishing market. Today, just describing records in bibliographic databases is not enough, articles have to be edited with a view to publishing them on the Internet, to make them 'visible', which improves their citation coverage. These are all things which people did not pay attention to in the past or which did not exist, for example, editing abstracts to include key words, positioning documents by means of metatags, optimisation of internal search engines and such like. This is very complex publishing engineering, making life difficult for editorial boards, which, mainly for financial 
reasons, cannot afford IT tools that are expensive to make and maintain.

- I am old-fashioned and fond of traditional ways of doing things and it seems to me that the paper version will last longer.

- No doubt it will. I, too, share your fondness for traditional books. However, science has opted for this particular way of distributing ideas and we have to adapt, if we want to survive, even if we don't always like it. That is why we pay so much attention to IT solutions, though at the same time we do not forget that the printed word is the foundation.

- Is Geographia Polonica included in the ISI Master Journal List?

- Unfortunately not yet. When the list was being created in the 1990s, we did not pay a lot of attention to it and, in a way, 'overslept' and missed the moment when getting included was fairly easy. Today it is much more difficult, because there is huge competition among journals, but we are making such an attempt now. A new editorial board has been in place for two years and its members really want Geographia Polonica to continue to be the most important voice of Polish geographers and a kind of 'conveyor belt' for what is best in Polish geography. Therefore, we not only try to acquire the best and most interesting papers, but sometimes also to translate those that have been published only in Polish so that they will not be forgotten. A lot of the material comes from other countries, especially from Central Europe.

- In that case it only remains for me to wish you success for the next fifty years, so different not only in terms of issues and concepts, but also the whole background work associated with publishing with which you have bewildered me at the end of our conversation. Good luck and satisfaction to the authors and the entire editorial team.

- Thank you very much for these wishes and this interview.

Professor Leszek Antoni Kosiński was interviewed by Przemysław Śleszyński.

Warsaw, 15 Janunary, 2014.

The Polish and English versions have been approved by the Author.

The interview was prepared in collaboration with Barbara Jaworska-Księżak.

(C) Leszek Antoni Kosiński - Przemysław Śleszyński

(C) Geographia Polonica

(C) Institute of Geography and Spatial Organization

Polish Academy of Sciences - Warsaw • 2014
Article first received • March 2014

Article accepted • May 2014 